\title{
Structural changes in the agricultural sector
}

\author{
Maria Tyapkina ${ }^{1 *}$, Viktor Samaruha ${ }^{2}$ Elena Ilina $^{1}$, and Yulia Mongush ${ }^{1}$ \\ ${ }^{1}$ Irkutsk State Agrarian University named after A. A. Ezhevskiy, 664038 Irkutsk, Russia \\ ${ }^{2}$ Baikal State University, 664000 Irkutsk, Russia
}

\begin{abstract}
The article aims to describe structural changes in the agrarian sector of Irkutsk region caused by the government support for small businesses, simplified procedures for farm registering, accounting for property and production results, and taxation, which contributed to the development of peasant farming. The government support is required, but it can change the structure of areas and gross grain crops since peasant farms increase quantitative indicators rather than improve quality parameters (yield, productivity). This is especially true for the animal husbandry sector. With changes in government policies and decreasing government support, it will be difficult for individual farms to exist, since they lag behind collective farms in terms of maneuverability, financial capabilities, production and credit resources, which can cause new structural changes in a benefit for agricultural holdings. The government policy aimed at preserving the traditional way of life of the rural population should stimulate both the development of rural areas and agricultural production, and prevent the disintegration of collective farms that have competitive advantages
\end{abstract}

\section{Introduction}

Peasant farms have a special economic and social significance associated with the production of agricultural products and preservation of the traditional way of rural life, ecological well-being [1, 2], and cultural heritage, which forces the government to search for new mechanisms to support them.

\section{Problem Statement}

Small farms have a small scale of production, limited maneuverability and limited access to financial and production resources; the quality of their material and technical base is low, and they have limited financial opportunities for its renewal [3]; the system of consolidation of economic interests within the consumer and industrial cooperation is underdeveloped. Other features of small farms are as follows: low innovation abilities [4] and weak susceptibility to innovation; insufficient competitiveness in the context of the underdeveloped competitive environment and dominant positions of large agribusinesses [5]; a high level of localization of local markets [6] and limited opportunities for entering new markets.

In Irkutsk, the share of agricultural products produced by small farms region increased by $6.8 \%$ for eight years (15.4\% in 2019) (in the Russian Federation, it is $13.7 \%$ ). In 2012-2019, the volume of household production increased 2.54 times due to an increase in the volume of production of milk, meat, cereals, potatoes and vegetables, sown areas and livestock. The sown area decreased in agricultural organizations but increased in small farms.

\section{Purpose of the Study}

The article aims to assess structural changes in the agricultural production of the region and results of the government grant support for peasant households.

\section{Research Questions}

One of the conditions for the effective work of peasant households is government support, which strengthens the material and technical base of farmers. The number of collective farms has decreased, while the number of peasant households has increased. In Irkutsk region, there were 178 collective farms in 2012 and 120 ones in 2019. This decrease was caused by the grant support. Since 2012 in Irkutsk region, the "Support for a novice farmer" and "Development of family livestock farms on the basis of peasant farms" programs have been implemented. Since 2013, the "Development of family dairy farms" program has been implemented; since 2015, the "Development of engineering infrastructure of public facilities of horticultural and horticultural non-profit partnerships" program has been implemented. Since 2016, the "Development of the material and technical base of agricultural consumer cooperatives" program has been implemented; and in 2019, the Agrostartup program was launched.

For small farms, the grant support is optimal, since it is target and available to most applicants. It is provided under transparent conditions [7].

\footnotetext{
Corresponding author: $\underline{\text { mft74@mail.ru }}$
} 
Table 1. Financing dynamics for grant programs intended for small businesses in Irkutsk region.

\begin{tabular}{|c|c|c|c|c|c|}
\hline Parameters & 2012 & 2013 & 2015 & 2016 & 2019 \\
\hline \multicolumn{6}{|c|}{ Novice Farmer Support Program } \\
\hline $\begin{array}{l}\text { Number of } \\
\text { grants }\end{array}$ & 36 & 57 & 80 & 78 & 38 \\
\hline $\begin{array}{l}\text { Subsidies, } \\
\text { million rubles }\end{array}$ & 47 & 84 & 119 & 113 & 114 \\
\hline \multicolumn{6}{|c|}{ Family Livestock Farm Development Program } \\
\hline $\begin{array}{l}\text { Number of } \\
\text { grants }\end{array}$ & 7 & 5 & 11 & 9 & 10 \\
\hline $\begin{array}{l}\text { Subsidies, } \\
\text { million rubles }\end{array}$ & 51 & 52 & 111 & 91 & 145 \\
\hline \multicolumn{6}{|c|}{ Development of family dairy farms program } \\
\hline $\begin{array}{l}\text { Number of } \\
\text { grants }\end{array}$ & - & 5 & 4 & 5 & 5 \\
\hline $\begin{array}{l}\text { Subsidies, } \\
\text { million rubles }\end{array}$ & - & 59 & 48 & 57 & 75 \\
\hline \multicolumn{6}{|c|}{$\begin{array}{l}\text { Development of engineering infrastructure of public } \\
\text { facilities of horticultural and vegetable gardening non- } \\
\text { profit partnerships program }\end{array}$} \\
\hline $\begin{array}{l}\text { Number of } \\
\text { grants }\end{array}$ & - & - & 11 & 10 & 26 \\
\hline $\begin{array}{l}\text { Subsidies, } \\
\text { million rubles }\end{array}$ & - & - & 5 & 5 & 13 \\
\hline \multicolumn{6}{|c|}{$\begin{array}{l}\text { Development of the material and technical base of } \\
\text { agricultural consumer cooperatives program }\end{array}$} \\
\hline $\begin{array}{l}\text { Number of } \\
\text { grants }\end{array}$ & - & - & - & 8 & 5 \\
\hline $\begin{array}{l}\text { Subsidies, } \\
\text { million rubles }\end{array}$ & - & - & - & 78 & 100 \\
\hline \multicolumn{6}{|c|}{ AgroStartUp program } \\
\hline $\begin{array}{l}\text { Number of } \\
\text { grants }\end{array}$ & - & - & - & - & 16 \\
\hline $\begin{array}{l}\text { Subsidies, } \\
\text { million rubles }\end{array}$ & - & - & - & - & 32 \\
\hline
\end{tabular}

Under the "Novice Farmer" program developed for 2012-2019, 463 grants in the amount of 782 million rubles were provided to farmers (the average size was 1,689.2 thousand rubles in 2012-2018, and 3,000 thousand rubles since 2019). Grants were used for purchasing agricultural machinery $(93 \%)$, breeding farm animals $(5 \%)$, land plots, seeds, fertilizers (2\%). Novice farmers created 967 jobs, developed more than 74 thousand hectares of agricultural land; 33 thousand hectares were registered under the ownership; they purchased more than 19.3 thousand heads of cattle, including nine thousand cows.

Under the "Development of a family livestock farm" program developed for 2012-2019, 69 grants in the amount of 719 million rubles were provided to farmers (the average grant size was 10 million rubles in 20122019, and 15 million rubles since 2019). Grants were used for the development of beef cattle breeding - 50 farms $(75 \%)$, dairy cattle breeding - 15 farms, pig breeding - 2 farms, sheep breeding - 2 farms. Since 2018, the program has covered such areas as rabbit breeding and goat breeding. Under this program, farmers increased the number of cattle up to 10.7 thousand heads with an average productivity per cow of more than 4500 $\mathrm{kg}$ (the average is $3280 \mathrm{~kg}$ ) and an average daily weight gain of $810 \mathrm{~g}$. Grant recipients created 191 new jobs, purchased 116 self-propelled agricultural machines and over 1600 heads of breeding animals. The funds were also used to construct, reconstruct and modernize farms and equipment.

Table 2. Directions for the use of grants provided to small businesses in Irkutsk region.

\begin{tabular}{|c|c|}
\hline Program & Directions \\
\hline $\begin{array}{l}\text { Support for a } \\
\text { novice farmer }\end{array}$ & $\begin{array}{l}\text { - purchase of agricultural machinery, } \\
\text { trucks, equipment for the production } \\
\text { and processing of agricultural products; } \\
\text { - purchase of breeding farm animals. }\end{array}$ \\
\hline $\begin{array}{l}\text { Development of } \\
\text { family livestock } \\
\text { farms }\end{array}$ & $\begin{array}{l}\text { - construction, reconstruction or } \\
\text { modernization of farms; } \\
\text { - equipping; } \\
\text { - purchase of breeding farm animals. }\end{array}$ \\
\hline $\begin{array}{l}\text { Development of } \\
\text { family dairy } \\
\text { farms }\end{array}$ & $\begin{array}{l}\text { - construction of dairy farms; } \\
\text { - equipping with agricultural } \\
\text { machinery, installation of machines; } \\
\text { - purchase of breeding animals. }\end{array}$ \\
\hline $\begin{array}{l}\text { Development of } \\
\text { engineering } \\
\text { infrastructure of } \\
\text { public facilities } \\
\text { of horticultural } \\
\text { and vegetable } \\
\text { gardening non- } \\
\text { profit } \\
\text { partnerships }\end{array}$ & $\begin{array}{l}\text { - power supply (construction, repair, } \\
\text { installation, replacement of power lines, } \\
\text { power grids, transformer stations, } \\
\text { purchase of electric motors, } \\
\text { technological equipment, components, } \\
\text { operating materials, spare parts); } \\
\text { - water supply (drilling of wells, } \\
\text { purchase (construction) of pumping } \\
\text { stations, construction, repair, } \\
\text { installation, replacement of water } \\
\text { pipelines, purchase of technological } \\
\text { equipment, components, operating } \\
\text { materials, spare parts; } \\
\text { - water disposal (purchase of } \\
\text { technological equipment, components, } \\
\text { operating materials, spare parts). }\end{array}$ \\
\hline $\begin{array}{l}\text { Development of } \\
\text { the material and } \\
\text { technical base } \\
\text { of agricultural } \\
\text { consumer } \\
\text { cooperatives }\end{array}$ & $\begin{array}{l}\text { - construction, reconstruction and } \\
\text { modernization of production facilities; } \\
\text { - purchase and installation of } \\
\text { equipment; } \\
\text { - purchase of specialized transport; } \\
\text { - payment of contributions under } \\
\text { leasing agreements. }\end{array}$ \\
\hline Agrostartup & - purchase of agricultural machinery. \\
\hline
\end{tabular}

Under the "Development of a family dairy farm" program developed for 2012-2019, 34 grants in the amount of 429 million rubles were provided to farmers (the average size of grant support is no more than 15 million rubles). The grants were intended for the construction of dairy farms, purchase of breeding cows, improvement of performance of agricultural machinery and equipment, which made it possible to achieve a $100 \%$ level of mechanization of milk production.

Since 2015, 205 horticultural non-profit partnerships have taken part in the Development of Engineering Infrastructure for Common Use Facilities of Horticultural and Horticultural Non-profit Partnerships program, of which 87 partnerships received grants in the amount of 500 thousand rubles. Since 2019, gardeners' non-profit organizations affected by floods received grants in the amount of up to 1 million rubles. The 
allocated funds were used to develop the internal infrastructure under co-financing (95\% of funds from the regional budget and $5 \%$ of funds from the horticultural non-profit partnerships). The total amount of funding amounted to 38 million rubles.

Under the "Development of the material and technical base of agricultural consumer cooperatives" program developed for 2016-2019, 33 grants in the amount of $379 \mathrm{mln}$. rubles were provided to farmers (the average size was over 12 million rubles; since 2020 it is 30 million rubles).

In 2019, under the Agrostartup program, 16 grants in the amount of 32 million rubles were provided (the average size was 2 million rubles), which made it possible to create 32 new jobs. The grant funds were used to purchase agricultural equipment.

Table 3. Cattle in Irkutsk region, thousand heads.

\begin{tabular}{|l|c|c|c|}
\hline \multicolumn{1}{|c|}{ Types of farms } & 2012 & 2019 & $\begin{array}{c}2019 / \\
2012, \%\end{array}$ \\
\hline All farms & 280 & 290 & 103.6 \\
\hline $\begin{array}{l}\text { Agricultural } \\
\text { organizations }\end{array}$ & 67 & 62 & 92.5 \\
\hline Individual farms & 184 & 154 & 83.7 \\
\hline Peasant farms & 29 & 74 & 255.2 \\
\hline
\end{tabular}

The number of cattle in agricultural organizations has decreased due to the low profitability of milk and meat production and low return on investment as a result of a long production cycle [8]. Reducing government support for the livestock sector forces agricultural enterprises to change their production structure [9]. The households have also reduced the number of heads due to the high fodder cost [10], the lack of opportunities for purchasing pedigree livestock and marketing problems. In 20122019, the number of cattle increased 2.6 times and amounted to 74 thousand heads, the number of cows increased 2.8 times or by 33 thousand heads. The number of horses increased by $31 \%$ and sheep - by $49 \%$.

Table 4. Sown areas in Irkutsk region, thousand hectares.

\begin{tabular}{|l|c|c|c|}
\hline \multicolumn{1}{|c|}{ Types of farms } & 2012 & 2019 & $\begin{array}{c}2019 / \\
2012, \%\end{array}$ \\
\hline All farms & 647.9 & 708.0 & 109 \\
\hline $\begin{array}{l}\text { Agricultural } \\
\text { organizations }\end{array}$ & 417.3 & 321.6 & 77 \\
\hline Individual farms & 45.6 & 27.1 & 59 \\
\hline Peasant farms & 185.0 & 359.2 & 194 \\
\hline
\end{tabular}

The sown area is increasing due to the use of fallow lands. In 2019, the sown area increased by 60 thousand hectares or $9 \%$ and amounted to 708 thousand hectares. There was a change in the sown areas cultivated in agricultural organizations - they decreased by $23 \%$; in individual farms, they decreased by $41 \%$, in peasant farms they increased 1.94 times or by 174 thousand hectares.

Small farms increased the volume of milk 2.1 times, meat - by $39 \%$, cereals - by $82 \%$, potatoes - by $40 \%$ and vegetables - by $8 \%$, both due to an increase in the yield (from $18 \mathrm{c} / \mathrm{ha}$ in 2012 to $20.6 \mathrm{c} / \mathrm{ha}$ in 2019 for grains, from $154 \mathrm{c} / \mathrm{ha}$ to $165 \mathrm{c} / \mathrm{h}$ a for potatoes, from $199 \mathrm{c} / \mathrm{ha}$ to $269 \mathrm{c} / \mathrm{ha}$ for vegetables). The number of livestock (from 28.6 thousand to 74.3 thousand heads) and sown areas (from 185 thousand to 359 thousand hectares, or by $94 \%$ ) increased either.

Table 5. Agricultural production in peasant (farm) farms of Irkutsk region, thousand tons.

\begin{tabular}{|l|c|c|c|}
\hline \multicolumn{1}{|c|}{ Products } & 2012 & 2019. & $\begin{array}{c}2019 / \\
2012, \%\end{array}$ \\
\hline $\begin{array}{l}\text { livestock and } \\
\text { poultry for } \\
\text { slaughter (slaughter } \\
\text { weight) }\end{array}$ & 5.6 & 7.8 & 139.3 \\
\hline milk & 29.4 & 62.8 & 213.6 \\
\hline cereals & 230.6 & 419.3 & 181.8 \\
\hline potato & 19.4 & 27.1 & 139.7 \\
\hline vegetables & 8.6 & 9.3 & 108.1 \\
\hline
\end{tabular}

Table 6. The share in the production by farms, $\%$.

\begin{tabular}{|c|c|c|c|c|}
\hline years & $\begin{array}{c}\text { All } \\
\text { farms }\end{array}$ & $\begin{array}{c}\text { Agricultural } \\
\text { organizations }\end{array}$ & $\begin{array}{c}\text { Individual } \\
\text { farms }\end{array}$ & $\begin{array}{c}\text { Peasant } \\
\text { farms }\end{array}$ \\
\hline \multicolumn{5}{|c|}{ Irkutsk region } \\
\hline 2012 & 100 & 41.8 & 49.6 & 8.6 \\
\hline 2019 & 100 & 44.6 & 40.0 & 15.4 \\
\hline \multicolumn{5}{|c|}{ RF } \\
\hline 2012 & 100 & 49.1 & 42.0 & 8.9 \\
\hline 2019 & 100 & 57.7 & 28.6 & 13.7 \\
\hline
\end{tabular}

In 2012, the largest share of agricultural products fell on household farms (49.6\%), agricultural organizations $(41.8 \%)$, peasant farms $(8.6 \%)$. There was an increase in the volume of production in collective and peasant farms in value terms; the share increased by $2.8 \%$ in agricultural organizations and by $6.8 \%$ in peasant farms. In 2019, the largest share of agricultural products fell on collective farms $-44.6 \%$, household farms $-40.0 \%$, and peasant farms - $15.4 \%$. Agricultural organizations implement innovation technologies, which make it possible to increase the crop yield and improve the animal productivity.

With an increase in the volume of milk production by 2.1 times and the number of cattle 2.8 times, the productivity of cows decreased by $23 \%$ and amounted to 1.8 tons. Farms receiving grant support were able to purchase breeding animals and increase productivity by $81 \%$.

Table 7. Milk per cow, kg.

\begin{tabular}{|c|c|c|c|c|}
\hline years & $\begin{array}{c}\text { All } \\
\text { types of } \\
\text { farms }\end{array}$ & $\begin{array}{c}\text { Agricultural } \\
\text { organization } \\
\text { s }\end{array}$ & $\begin{array}{c}\text { Individu } \\
\text { al farms }\end{array}$ & $\begin{array}{c}\text { Peasant } \\
\text { farms }\end{array}$ \\
\hline \multicolumn{5}{|c|}{ Irkutsk region } \\
\hline 2012 & 3412 & 4088 & 3367 & 2471 \\
\hline 2019 & 3846 & 5698 & 3441 & 1892 \\
\hline \multicolumn{5}{|c|}{ RF } \\
\hline 2012 & 3898 & 4521 & 3486 & 3372 \\
\hline 2019 & 4642 & 6290 & 3471 & 3791 \\
\hline
\end{tabular}




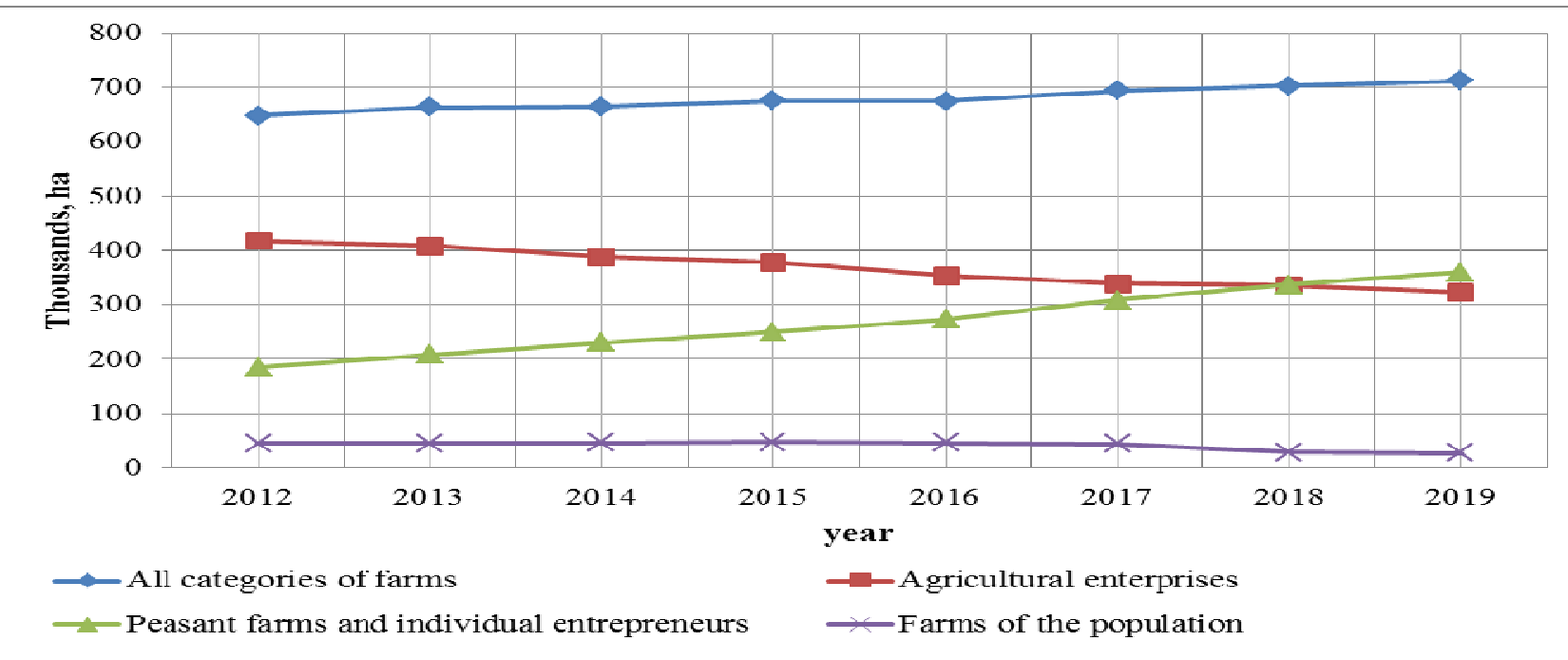

Fig. 1. The dynamics of sown areas for different types of farms in Irkutsk region

As for the sown area, structural changes are evident: in 2012, collective farms owned $65 \%$ of the sown area, while in 2019 individual farmers owned $45 \%$ (in Russia, these shares are $73 \%$ and $66 \%$, respectively). As for the qualitative changes, in 2012 the grain yield was higher in individual farms (1.75 tons versus 1.54 tons). By 2019, the ratio was 1.79 tons to 1.82 tons.

Table 8. The results of activities of farms in Irkutsk region during the support period.

\begin{tabular}{|l|c|c|c|}
\hline & 2012 & 2019 & $\begin{array}{c}2019 / \\
2012, \%\end{array}$ \\
\hline Number of farms * & 735 & 1291 & 176 \\
\hline $\begin{array}{l}\text { Income, million } \\
\text { rubles }\end{array}$ & 2555 & 6983 & 273 \\
\hline $\begin{array}{l}\text { Expenses, million } \\
\text { rubles }\end{array}$ & 2475 & 6418 & 259 \\
\hline $\begin{array}{l}\text { Government } \\
\text { support (budget } \\
\text { subsidies), million } \\
\text { rubles }\end{array}$ & 473 & 1927 & 408 \\
\hline $\begin{array}{l}\text { Share of } \\
\text { government support } \\
\text { to income, } \%\end{array}$ & 18.5 & 27.6 & 149 \\
\hline $\begin{array}{l}\text { Average monthly } \\
\text { wages of } \\
\text { employees, } \\
\text { thousand rubles }\end{array}$ & 7.2 & 15.0 & 211 \\
\hline * according to the annual reports of the Ministry of Agriculture \\
of Irkutsk Region
\end{tabular}

The lack of personnel, low wages, and nonobservance of agricultural technologies decreased the yield of individual farms in comparison with the collective ones.

For the eight-year period of grant support for small businesses, the number of farms that submitted reports to the Ministry of Agriculture has increased by $76 \%$. With a four-fold increase in the volume of government support, the income of farmers increased 2.7 times. The share of government support in the farmers' income increased from $18.5 \%$ in 2012 to $27.6 \%$ in 2019 . The average monthly wage is only $43 \%$ of the industry average (in 2019, the average wage was 34.6 thousand rubles).

\section{Conclusion}

Structural transformations differ in their intensity, but currently we are observing significant institutional changes in the production process, an increase in the number of cows and sown areas in small farms. However, these changes do not solve the issue of grain and milk yields which remain low. The factors hindering the development of farming are a low level of development of animal husbandry, low productivity of natural forage lands, limited access to financial resources on preferential terms, slow development of production and market infrastructures, low rates of renewal of the material and technical base. The ongoing structural changes in the regional agriculture do not increase the volume of agricultural production, since small farms prefer an extensive type of production. A new government policy should be developed and implemented. In crisis conditions, the development of a highly efficient agricultural sector becomes an urgent task.

\section{References}

1. R.T. Adarina, A.V. Glotko, T.A. Kuttubaeva, O.N. Shvakova, X.G. Yankovskaya, "Green economy" indicators as a foundation for the development of the regional economy, International Journal of Innovative Technology and Exploring Engineering, 8(8) (2019)

2. A.M. Bondarenko, V.I. Savkin, S.A. Shelkovnikov, L.S. Kachanova, Approaches to the economic evaluation of elements of organic agricultural production of innovative type, Astra Salvensis, 7(51) (2019)

3. A. Nechaev, A. Rasputina, Integrated depreciation management system, IOP Conference Series: Earth and Environmental Science, 32011 (2020)

\footnotetext{
Corresponding author: $\underline{\text { mft74@mail.ru }}$
} 
4. A.S. Nechaev, D.V. Ognev, O.V. Antipina, Innovation risks: challenges and prospects, Advances in Economics, Business and Management Research, 38 (2017)

5. G.M. Vinokurov, M.V. Vinokurov, State and prospects for the development of crop production in the agro-industrial complex of Irkutsk region, Economics and Management: Problems, Solutions, 5 (2017)

6. A.I. Mamaeva, G.M. Vinokurov, Development of the region's pig production market based on the cluster approach, IOP Conference Series: Earth and Environmental Science, 012098 (2019)

7. O.N. Kobtseva, R.A. Shichiyakh, E.V. Sidorchukova, N.N. Novoselova, S.N. Novoselov, D.E. Morkovkin, Organizational and economic features of import substitution formation and realization in the conditions of spatial restrictions, International Journal of Applied Business and Economic Research, 15(23) (2017)

8. M.F. Tyapkina, Rating of agricultural enterprises of irkutsk region based on multivariate analysis, European Proceedings of Social \& Behavioural Sciences, 1285-1294 (2018)

9. S. Baskakov, E. Rudoy, I. Vorotnikov, I. Sukhanova, M. Glukhova, Food balancing assessment: a three-way approach, International Journal of Economics and Business Administration, 8(1) (2020)

10. M.F. Tyapkina, V.V. Vrublevskaya, V.I. Samarukha, Assessment of reproduction of agricultural products, IOP Conference Series: Earth and Environmental Science, 22092 (2019) 